\begin{tabular}{ccc}
\hline INTERnals & $\begin{array}{c}\text { INTEUSTRIAL } \\
\text { ORGANIZATIONAL LEADERSHIP }\end{array}$ \\
MANAGEMENT \\
\hline
\end{tabular}

\title{
The effect of Islamic work ethics on the performance of Muslim employees of marketing sector in multinational companies
}

\author{
Mitra Hadisi \\ Department of Executive Management, Science and Research Branch, Islamic Azad University, Ardabil, Iran.
}

\begin{tabular}{ll}
\hline & ABSTRACT \\
\cline { 2 - 3 } Keywords: & $\begin{array}{l}\text { This study investigates the effect of Islam on efficiency of Muslim employees in multinational } \\
\text { companies. The findings of the studies conducted to date examining the potential and actual } \\
\text { impact of Islam in multinational setting indicates that although it seems that religion has no } \\
\text { Muslim Employees, } \\
\text { Multinational Companies, } \\
\text { Ethics }\end{array} \quad \begin{array}{l}\text { significant effect on multinational companies, but its internal effects such as internal and } \\
\text { interpersonal conflicts with the type of activity of companies may be intensified. Moreover, } \\
\text { these effects would be different based on the department of individual employees. For } \\
\text { example, when the religious orientations of Muslims increase, their activities, according to the } \\
\text { type of the product or service provided, in marketing sector of multinational companies may } \\
\text { be affected. As the products and services offered would have more moral dimensions and } \\
\text { marketing activities would be based on general moral rules, not a particular religion, we may } \\
\text { achieve more effective results and personal and interpersonal conflicts can be reduced. }\end{array}$ \\
Correspondence: &
\end{tabular}

(C)AIMI Journals

\section{Introduction}

The multinational companies'(MNCs) activities play an undeniable role in different areas and countries, especially in Muslim areas. In most of such companies, there are workforces with diverse perspectives and religions. Despite growing prominence of Muslims' markets, researchers have turned a blind eye to Islamic viewpoint in the global business though there are some exceptions (Rice, 1999). 
The existing international ethical principles in the multinational companies can cause internal or external conflict between persons with different ethical approaches such as Islam and those with the approach prevalent in the company. In fact, the study of work ethics has attracted growing interest in recent years. However, most studies undertaken on this area, as well as the vast subject area of business ethics, had their basis in the experiences which were related to either American or some European countries (Lim \& Say, 2003; Rizk, 2008). Furthermore, the studies such as Furnham $(1982,1990)$ and Furnham and Rajamanickam (1992) were based on the Protestant Work Ethic (PWE) (Lessnoff, 1994).

Despite the effect of Protestant principles and work ethics on the economic development of the West and its impact on enterprises and marketing (A. Kuzma, A.Kuzma, \& J. Kuzma, 2009), the function of the models lying (Sood \& Nasu, 1995) might face some constraints in non-western communities and multinational companies. One of the reasons which can impose such constraints is the varying religions of the employees working in different sectors.

Islam is one of the major religions in the world. The concept of ethics in Islam is derived from the Qur'an and Sunnah. It should be mentioned that in a manner similar to Weberian Protestantism, Islam provides the ideological foundation for a variety of personal attributes whereby it can promote economic development (Ali, 1992).

Najjar (1992) emphasizes that Egyptians and other Middle Eastern people perceive capitalism and socialism as the cause of rapid deterioration of the quality of Islamic life, however, not much is known about Islamic work ethics (IWE). To date, there are only a few researches that have taken IWE into their consideration (Ali, 1988, 1992; Ali \& Al-Kazemi, 2007; Rahman, Mohammad, \& Othman, 2006; Yousef, 2000, 2001).

A review of the literature, to the best of my knowledge, shows a general lack of any published Islamic perspectives on the various aspects of business including marketing and ethics. According to the factors which determine an ethical decision making process, several secular theories have been put forward over the years including utilitarian, justice, and fairness theories (e.g., Adler \& Borys, 1993; Bayles, 1968; Fraedrich, 1993; Gaertner, 1994; Helms \& Hutchins,1992; Hollingsworth, 1991; Maclntyre, 1981; Rawls, 1971; Reidenbach et al., 1991). The utilitarian grounding of ethical behavior places a greater emphasis on positivism approaches while ignoring the transcendental aspects, i.e., the actualization of higher spiritual objectives of life.

The studies, which have focused on the ties between religion and behavior, have strongly supported the effect of religion on individual's emotional experience, thought, behavior, and 
psychological states (Chamberlain \& Zika, 1992; McDaniel \& Burnett, 1990; Pollner 1989; Witter, Stock, Okun, \& Haring, 1985). McDaniel and Burnett (1990) came to the conclusion that those with deep religious beliefs place higher value on friendship, guidance, and help offered by selling sector's staff. They argued that it might be as a result of further sociability of customers who hold stronger religious beliefs.

By looking from different view, it should be mentioned that the MNCs' increased role in the current age of globalized economy, calls our attention to cognition and perception of Islamic outlook's stimuli as an essential condition. In such condition, a proper understanding of Muslim customers' minds and thoughts can be achieved, while in the case that there is inaccurate perception and understanding of the Islamic principles and the practical code is not followed; the international business persons, vendors, and investors not only will be at the stake of distorting substantial part of their target markets, but also will be at the risk of having direct conflict with them (Rogers, Ogbuehi, \& Kochunny, 1995).

Marketing sector in MNC is one of the sectors where conforming internally to norms, rules, approaches, and compatibility with staff's ethical principles are of great importance.

\section{Work Ethics}

Historically speaking, a cultural norm leaves one with great feeling to adequately perform a task, since the internal value of work lies in its performance (Lipset, 1990). From Greeks', Jews', and even Romans' perspectives work considered as a disaster or suffering (Maywood, 1982; Roze, 1985; Tilgher, 1930).

In spite of the prominent role of Protestantism in shifting attitudes towards work in the West, the significant part of Islam cannot be discarded. All the individuals' entrepreneurial endeavors such as their professions are rooted in and are part of their religious beliefs (Al Fraruqi, 1992). From Islamic perspective, all vocations related to business, including domestic and international marketing are form of worshiping; business, indeed, in itself is considered as communion with God (Quran 107:1-7).

IWE can be defined as a set of moral principles that distinguish what is right from wrong in the Islamic context (Beekun, 1997). These limited studies on IWE indicate that it may share a number of commonalities with PWE. For instance, both IWE and PWE place considerable emphasis on hard work, commitment, and dedication to work, work creativity, avoidance of unethical method of wealth accumulation, cooperation, and competitiveness at work place (Yousef, 2001). 
Islam clearly counters the Weber's thesis (1958) that Muslim societies could not develop their economy. Research studies conducted by Arslan (2000, 2001) have provided empirical support to refute Weber's thesis. Arslan (2000) compared the performance of the British and the Turkish managers using PWE. In his conclusion, Arslan mentioned that the religious motives with their important impact on business, Islamic ethics, and heritage had principal effect on the business ethics.

\section{Business from Islamic Perspective}

Islam refers to business as a sine qua non of human life. It is such an essential factor that before the prophet Mohammad's mission inception, God guided him to become a successful merchant in the first place (Antonio, 2007; Trim, 2009). When the international marketing practices proceeds forward on the basis of firm ethical principles, it can take a pivotal role in developing universal business standards. Advocating of ethical principles can help to raise behavioral standards and consequently entail the welfare of merchants and customers.

Hanafi and Salam (1988) have referred to six aspects of ethical principles that can be observed in marketing activities including integrity, trust, purity of intention, fraternity, using science and technology, and justice. Rice and Al-Mossawi (2002) have also mentioned some dimensions about Islamic values such as style of relationships, honesty in communication, the protection of human race diversity, justice and fairness, highlighting the women's role in society, consumption ways, chastity, and respect for the environment while adopting strategies for advertising.

\section{The Relationship between MNCs' Marketing and Islamic Principles}

Although the marketing unit is not the only unit having a major part in determining the success of companies, its key role cannot be assuredly denied. When delivering products and services, the companies are expected to act in accordance with accepted principles of ethics (Antonio, 2007; Trim, 2009).

According to Rashid (2000), many righteous Muslim leaders are strongly committed, respectable, possess great wisdom, and do things according to the commands of the Qur'an. Describing some characteristics of righteous leaders Rashid and Mamat (2013) stated that these faithful leaders enjoy doing good deeds and strive to increase them. They make every effort to prevent evil and not to harm other people. Such leaders rush to perform good deeds as if they are in competition with each other. They are sincere and honest followers of Islam. 
They feel concern about their disciples and are aware of their responsibilities. Indeed, Allah does love those who are fair (Quran 43: 9). What makes distinction between Islamic and western communities' leaderships is the Islamic leaders' close adherence to religion, in particular to its ethical aspects and the individuals’ origins (Aabed, 2006).

The findings of research conducted to date indicate that IWE has directly affected both organizational commitment (Kidron, 1978; Peterson, 2003; Yousef, 2001) and job satisfaction (Koh \& Boo, 2001; Viswesvaran \& Deshpande, 1996; Vitell \& Davis, 1990; Yousef, 2001). Research has also shown that work ethic is related to organizational commitment as well (Kidron, 1978; Peterson, 2003; Yousef, 2001). In sum, work ethics are closely related to job satisfaction (Koh \& Boo, 2001; Viswesvaran \& Deshpande, 1996; Vitell \& Davis, 1990; Yousef, 2001).

\section{Establishing Relationship}

In general, there are four properties surrounding the concept of marketing, namely spirituality, ethics, ingeniousness, and altruism (Sula \& Kartajaya, 2006). According to them marketers are assumed to be able to foster the spirit of Islam in all aspects of marketing activities, from the planning stage to post-sale services. Increasing spirituality in Islamic marketing can lead to enhancing Islamic ethics in commercial transactions. From marketing perspective, ingeniousness (being realistic) connotes an opportunity to be creative. Arham (2010) states that Altruism is another property which can influence marketing principles. Modern marketing refers to altruism as sustainable marketing which is essentially a marketing concept that tries to strike a balance between market demand and maintaining the environment (Kotler \& Armstrong, 2010).

However, despite external compliance of staff with company's rules, the differences between Protestantism approaches in multinational companies and Muslim staff's Islamism can cause problems in the internal compliance of some of rules and the related moral issues. These problems merit consideration from two aspects: internal and external conflicts. The external conflict makes reference to the tension between a Muslim employee and a company, whereas the internal conflict denotes the amount of tension between an individual's religious beliefs and type of job which can be examined regarding several important dimensions. 


\section{The Way of Providing Products and Services}

In recent decades, a significant and growing percentage of Islamism among Muslim geographers has been seen and several studies on the Islamic dynamism have been conducted (Bayat, 2005; Esposito, 1998; Wiktorowicz, 2004). For example, the number of hotels based on the Islamic patterns has increased. In these hotels, the types of services offered or customer classification have been with respect to their religion and have had a great effect on tourism marketing. As a matter of fact, the kind and nature of the products that are presented at international companies marketing department has a direct impact on the internal tensions of the Muslims working in the marketing sector which can be divided into two categories, namely type of product and its introduction.

According to Islamic code, production and sale of certain products, such as alcoholic drinks (Quran 2: 219), carrion and pork (Quran 5: 4) is forbidden and is not permissible. There is also another important issue which is not only related to the nature of the product itself, but also covers the process of producing the product. In brief, being halal is one of the conditions for the use of the products. Islamic slaughtering and marketing of these products or products derived from them can increase the internal stress of an individual.

Thus, a Muslim producer or marketer needs to be honest and take full responsibility for all the products he makes. Consequently, accepting marketing of such products can entail internal conflict between a Muslim and type of his work.

\section{The Way of Producing New Product}

As Al-Ghazali (1983) introduced, some products imposes some requirements to be fulfilled. For example, having no Islamic Hijab of female Muslim staff in the marketing sector of MNCs, selling cosmetic products, and using sexual attraction in advertisements of these companies are considered taboo from Islamic perspective. Another aspect manifests itself in pricing.

According to Abu Dawud (1990), hoarding to make huge profit is not allowed in Islam, especially for essential food. He stated that a sinner can just withhold goods till their prices rise. Al-Buraey (1983) referred to the issue of monopoly and predatory pricing (dumping) in Islam; in his view, monopoly is the sole controller of market. One of the problems in multinational companies' marketing deals with the points advertised which might be false.

As Rice (1999) indicated, business and consumer decisions mostly pass through a moral filter before they are subject to the discipline of the market. For example, if seller is aware 
of any defect in the article which he/she is selling, he/she is Islamicly required to disclose it to the buyer, either Muslim or non-Muslim.

Thus, within the Islamic framework, the promotional techniques must not use sexual appeal, emotional, fear appeals, false testimonies, and other prohibited activities.

\section{Discussion}

In some regions like Middle East where people are closely adhered to their religious beliefs and cultural identity (Najjar, 1992; Rice, 1999), multinationals not only embark on marketing in these markets, but also they have employees of the same markets. One of the most critical sectors of these companies is marketing sector. Muslim workers in these sectors are possibly faced with a dichotomy, which can vary depending on some variables, like degree of faith and age (Mullin, Singhapakdi, Attia, \& Vitell, 2004).

The conflicts among these employees were discussed in this article. These conflicts were divided in two categories. First one was the external conflict that emanates from religiousIslamic beliefs, and the nature of job and organization, and can affect the interpersonal relationships among the employees and result in the separation of the individual from the organization. But another type of conflict which was the focus of this paper is the internal conflict between an individual's religion and his vocational activities that may not cause any kind of external tension for a long time. This conflict was discussed in several categories. First, the general principles of capitalism and Islamic view to business were pointed out. The existing differences between these two perspectives determine that Islam orientation is to promote community welfare and to avoid individualism. Furthermore, the positive and direct effect of Islam on employees, i.e., dedication to work was explained in detail.

Moreover, the overall performances of marketers in this study were classified into two groups. First is the product itself and its nature and the second is the way of presenting product. Taking Islamic approaches into account, it was described that whenever Muslim workers face cases against their religious principles, i.e., offering forbidden foods, alcoholic drinks' marketing, sexual interactions, or providing services and products in ways contrary to Islam, namely dumping, false price increases, and deceptive advertising, a kind of conflict arises within them.

In sum, it can be concluded that internal conflict not only can affect Muslims' performance in the MNCs, but also can influence the performance of employees with other religions. In order to improve the performance of MNCs, a general survey of such 
relationship for each single religion seems necessary. Also noteworthy is the requisiteness of work - religion compliance for each individual. This issue opens up a new area of study on the characteristics of job and workers. As the above discussion attests, type of job must be associated with the religious requirements of a person. To achieve such conformity, the marketing department and even policy-making circles can charge employees with marketing in countries, based on their religious differences. Put differently, MNCs, in order to become well developed, can accept religious differences and do the planning, instead of ignoring them and following secularism in their activities. Religious beliefs are crucial to gain personal insight into individuals, exist in all cultures (Atran \& Norenzayan, 2004; Norenzayan \& Heine, 2005; Tarakeshwar, Stanton, \& Pargament, 2003). In a nutshell, taking them into consideration can positively affect the relationship between company and customers as well.

\section{References}

Aabed, A. (2006). A study of Islamic leadership theory and practice in K-12 Islamic School in Michigan (Unpublished doctoral dissertation). Brigham Young University, England.

Abu Dawud. (1990). Sunan Abu Dawud. New Delhi: Kitab Bhavan

Al-Buraey. (1983). Miskeen ad-darmi: First marketing expert in Islam. Al-IKtisad, 245(26), 42-49.

Al-Faruqi, I. R. (1992). Al tawhid: Its implications for thought and life. Herndon, VA: International Institute of Islamic Thought.

Al-Ghazali, M. (1983). Muslim characters. Srinagar: MWS.

Ali, J. A. (1988). Scaling an Islamic work ethic. Journal of Social Psychology, 128(5), 575-583.

Ali, J. A. (1992). Islamic work ethic in Arabia. Journal of Psychology, 126 (5), 507-517.

Ali, J. A., \& Al-Kazemi, A. (2007). Managerial problems in Kuwait. The Journal of Management Development, 21(5), 366 375.

Antonio, M. S. (2007). Muhammad SAW: The super leader super manager. Prophetic leadership and management centre: Jakarta.

Arslan, M. (2000). A cross cultural comparison of British and Turkish managers in term of Protestant work ethic characteristics. Business Ethics: A European Review, 9(1), 13-19.

Arslan, M. (2001). The Work ethic values of Protestant British, Catholic Irish and Muslim Turkish Managers. Journal of Business Ethics, 31(4), 321 -339.

Atran, S., \& Norenzayan, A. (2004). Religion's evolutionary landscape: Counterintuition, commitment, compassion, communion. Behavioral and Brain Sciences, 27(6), 713-730.

Bayat, A. (2005). Islamism and social movement theory. Third World Quarterly, 26(6), 891-908.

Beekun, R. (1997). Islamic business ethics. Herndon, VA: International Institute of Islamic Thought.

Chamberlain, K., \& Zika, S. (1992). Religiosity, meaning in life, and psychological well-being. In J. F. Schumaker (Ed.), Religion and mental health (pp.138 -148). New York: Oxford University Press.

Esposito, J. L. (1998). Islam and politics (4 ${ }^{\text {th }}$ ed.). Syracuse: Syracuse University Press.

Furnham, A. (1982). The Protestant work ethic and attitudes towards unemployment. Journal of Occupational Psychology, 55(4), 277-285. 
Furnham, A. (1990). The protestant work ethic: The psychology of work-related beliefs and behaviors. London: Routledge.

Furnham, A., \& Rajamanickam, R. (1992). The Protestant work ethic and just world belief in Great Britain and India. International Journal of Psychology, 27(6), 401-416.

Kidron, A. (1978). Work values and organizational commitment. Academy of Management Journal, 21(2), $239-247$.

Koh, H. C., \& Boo, E. H. (2001). The link between organizational ethics and Job satisfaction: A study of managers in Singapore. Journal of Business Ethics, 29(4), 309-324.

Kotler, P., \& Armstrong, G. (2008). Principles of marketing (12 ${ }^{\text {th }}$ ed.). New Jersey: Prentice Hall.

Kuzma, A. T., Kuzma, A. J., \& Kuzma, J. R. (2009). How religion has embraced marketing and the implications for business. Journal of Management and Marketing Research, 2, 1-10.

Lessnoff, M. H. (1994). The spirit of capitalism and the protestant ethic: An enquiry into the Weber thesis. Aldershot: Edward Elgar.

Lim, C., \& Lay, C. S. (2003). Confucianism and the protestant work ethic. Asia Europe Journal, 1(3), 321-322.

Lipset, S. M. (1990). The work ethic - then and now. Public Interest, 98, 61-69.

Maywood, A. G. (1982). Vocational education and the work ethic. Canadian Vocational Journal, 18(3), 7-12.

McDaniel, S.W., \& Burnett, J. J. (1990). Consumer religiosity and retail store evaluative criteria. Journal of the Academy of Marketing Science, 18(2), 101-112.

Mullin, M, J., K., Singhapakdi, A., Attia, A., \& Vitell, S. J. (2004). Some important factors underlying ethical decisions of Middle-Eastern marketers. International Marketing Review, 21(1), 53-67.

Najjar, A. (1992). Mabahith fi minhajiyyat al-fikr al-Islami. Beirut: Dar al-Gharb al-Islami.

Norenzayan, A., \& Heine, S. J. (2005). Psychological universals: What are they and how can we know. Psychological Bulletin, 131(5), 763-784.

Peterson, D. K. (2003). The relationship between ethical pressure, relativistic moral beliefs, and organizational commitment. Journal of Managerial Psychology, 16(6), 557-572.

Pollner, M. (1989). Divine relations, social relations, and wellbeing. Journal of Health and Social Behavior, 30(1), 92 -104.

Rahman, N. M., Muhamad, N., \& Othman, A. S. (2006).The relationship between Islamic work ethics and organizational commitment: A case analysis. Malaysian Management Review, 41(1), 79-89.

Rashid, A. (2000). Taliban: Militant Islam, Oil, and Fundamentalism in Central Asia. New Haven: London.

Rashid. A. A., \& Mamat. A. (2013). Educational view of the Islamic leadership: Are the Islamic leaders performing their responsibilities. International Journal of Humanities and Social Science, 3(3), 178-185.

Rice, G. (1999). Islamic ethics and the implications for business. Journal of Business Ethics, 18(4), 345-358.

Rice, G., \& Al-Mossawi, M. (2002). The implications of Islam for advertising messages: The Middle Eastern context. Journal of Euromarketing, 11(3), 71-96.

Rizk, R. R. (2008). Back to basics: An Islamic perspective on business and work ethics. Social Responsibility Journal, 1(2), 246-254.

Rogers, H. P., Ogbuehi, A. O., \& Kochunny, C. M. (1995). Ethics and transnational corporations in developing countries: A social contract perspective. Journal of Euromarketing, 4(2), 11 -38.

Rose, M. (1985). Reworking the work ethic: Economic values and socio-cultural politics. London: Schocken.

Saeed, M, Z., Ahmed, U., \& Mukhtar, S. M. (2001). International marketing ethics from an Islamic perspective: A value maximization approach. Journal of Business Ethics, 32(2), 127 -142.

Sood, J., \& Nasu, Y. (1995). Religiosity and nationality: An exploratory study of their effect on consumer behavior in Japan and the United States. Journal of Business Research, 34 (1), 1 -9.

Sula, M. S., \& Kartajaya, H. (2006). Shariah marketing. Mizan: Bandung.

Tarakeshwar, N., Stanton, J., \& Pargament, K. I. (2003). Religion: An overlooked dimension in cross-cultural psychology. Journal of Cross-Cultural Psychology, 34, 377 -394.

Tilgher, A. (1930). Homo Faber: Work through the ages (D. C. Fisher, Trans). New York, NY: Harcourt Brace.

Trim, B. (2009). Brilliant Entrepreneur Muhammad SAW. Bandung: Salamadani Pustaka Semesta. 
Vitell, S. J., \& Davis, D. L. (1990). The relationship between ethics and Job satisfaction: An empirical investigation. Journal of Business Ethics, 9, 489 -494.

Viswesvaran, C., \& Deshpande, S. P. (1996). Ethics, success, and job satisfaction: A test of dissonance theory in India. Journal of Business Ethics, 15, 1065 -1069.

Weber, M. (1958). The Protestant ethic and the spirit of capitalism. New York: Scribner's Press.

Wiktorowicz, Q. (2004). Islamic activism: A social movement theory approach. Bloomington, IN: Indiana University Press.

Witter, R., Stock, W., Okun, M., \& Haring, M. (1985). Religion and subjective well-being in adulthood: A qualitative synthesis. Review of Religious Research, 26, 332 -342.

Yousef, D. A. (2000). Organizational commitment as a mediator of the relationship between Islamic work ethic and attitudes toward organizational change. Human Relations, 53(4), 513 -537.

Yousef, D. A. (2001). Islamic work ethic: A moderator between organizational commitment and job satisfaction in a crosscultural context. Personnel Review, 30(2), $152-165$. 